Saeculum Christianum

vol. XXII (2015)

pp. $286-294$

ROMAN POLETYLO *

Archiwum UKSW, Warszawa

\title{
THE OPERATION OF THE CARDINAL STEFAN WYSZYŃSKI UNIVERSITY (WARSAW) ARCHIVE BASED ON ITS REPORTS FROM 2003 TO 2015
}

The Archive of Cardinal Stefan Wyszyński University in Warsaw (hereinafter referred to as the CSWU Archive or the Archive) was established by directive no.7/2000 of the Rector of Cardinal Stefan Wyszyński University in Warsaw dated on the 1st of September 2000 concerning formation of the archive and implementation of administrative standards and basic documents regulating circulation of the university files and documents. Therefore, the 15th anniversary of the foundation of the Archive at the Cardinal Stefan Wyszyński University appears to be a proper opportunity to discuss operation of the Archive. Reporting the measurable and calculable results of the work of the Archive employees is of the utmost importance. The archive, as a supervised unit keeping e.g. archive material, is required, among other obligations, to produce annual reports on its operation and lodge these reports by the end of March with the State Archive in Warsaw. However, that is not all. As the author will prove below the reports produced by the archivists over the last 15 years include annual reports (including partitive reports for annual academic reports) and multi-annual reports for the internal use of Rectors and Vice-Rectors supervising the CSWU Archive.

In the introduction it is prudent to present the character of university archives to better understand the manner in which they operate. The CSWU Archive is a state archive entrusted with particular resources: it contains historical resources and is obliged to collect, register and share documentation and keep its files until the university exists without the need to hand over the files to an appropriate state archive. The educational-scientific-research character the archive should express is also of importance.

The resources of the CSWU Archive constitute a singular, open archival fond. It compiles and provides access to the files of former Academy of Catholic Theology in Warsaw and the files of Cardinal Stefan Wyszyński University in Warsaw. Substantively it is subordinate to the State Archive in Warsaw. The State Archive in Warsaw supervises the CSWU Archive, issues permission to destroy the unnecessary documentation and re-certify remaining documents. The State Archive does not receive documentation from the CSWU Archive.

The CSWU Archive is a non-departmental unit of the Cardinal Stefan Wyszyński University in Warsaw and is directly subordinate to one of Vice-Rectors of the University. Resources of the archive include Academy of Catholic Theology documentation (1954-1999 archival fond, historical influx existing before the foundation of the CSWU Archive, mainly

* Translated by Spektra Sp. z o.o. 
students' files) as well as the files compiled and registered after foundation of the CSWU Archive (archival fond of the Cardinal Stefan Wyszyński University in Warsaw, 1999-present, mainly students' files, service records of ACT and CSWU employees, doctoral thesis, postdoctoral proceedings, professorial applications, photography, films, audio recordings).The Archive is in possession of numerous historically valuable pieces of documentation used by researchers of academic and national history as well as other scholars (the Archive is being used by e.g. writers, journalists). However, the majority of the fond consists of available current administrative documents (particularly Dean's Office documentation).

Before proceeding with the description of individual reports on the activities of the CSWU Archive it is prudent to indicate the tasks and responsibilities of the Archive. Realization of these tasks is visibly reflected in these very reports.These tasks are:

1. receiving documentation from all organizational units of the university;

2. storing documentation in correct order;

3. registering and compiling documentation in possession of the Archive;

4. conducting information activities (organizing social queries);

5. making documentation available to other organizational units of CSWU and lending documentation;

6. controlling processing of the documentation in registries of CSWU organizational units;

7. supervision of the destruction of unnecessary documentation;

8. participation in the work of the so called Archival Commission for Ascertainment of Documentation.

In 15 years of its existence the CSWU Archive documented realization of these tasks in reports drawn up in years 2003-2015 and presented herein in chronological order:

1. Report on the operation of the Archive in the academic year 2002/2003';

2. Report on the operation of the Archive in the academic year 2003/20042;

3. Report on the operation of the Archive in the academic year 2004/2005;

4. Report on the operation of the Archive in the academic year 2005/2006 ;

5. Report on the operation of the Archive in year $2006^{5}$;

\footnotetext{
1 Archive of Cardinal Stefan Wyszyński University in Warsaw (hereinafter: the CSWU Archive), Plans and annual reports of the CSWU Archive, current files with no archival signature. This report is an appendix to the document no. AUKSW-033-1/03 dated on the 29th of October 2003 and it is a response for the request of Ministry of National Education and Sport demanding creation of the CSWU Rector report concerning the activities of organizational units of the university.

2 Ibidem. It is an appendix for the document no. AUKSW-033-1/04 dated on the 30th of September 2004 and it is a response for the request to forward partial reports attachments for the annual CSWU Rector report concerning the activities of organizational units of the university.

3 Ibidem. It is an appendix for the document no. AUKSW-033-1/05 dated on the 30th of August 2005.Similarly to the previous cases it is the result of the necessity to fulfill obligations imposed by the Higher Education Act, mainly the requirement to lodge an annual report concerning the operation of the University with Ministry of National Education and Sport. It was mainly a matter of updating the data delivered with the previous Rector report on the operation of the university.

4 Ibidem. It is an appendix for the document no. AUKSW-033-1/06 dated on the 22nd of September 2006 and it is a response for the request for the unit's annual report issued by the university authorities.

5 Ibidem. It is an appendix for the document no. AUKSW-033-1/07 dated on the 20th of April 2007 (for the CSWU Rector's Office).
} 
6. Report on the operation of the Archive in years 2000-20076;

7. Report on the operation of the Archive in year 20077;

8. Report on the operation of the Archive in year $2008^{8}$;

9. Report on the operation of the Archive in year $2008^{9}$;

10. Report on the operation of the Archive in year 200910;

11. Report on the operation of the Archive in years 2000-2010

12. Report on the operation of the Archive in year $2010^{12}$;

13. Report on the operation of the Archive in year 201133;

14. Report on the operation of the Archive in the academic year 2010/2011

15. Report on the operation of the Archive in the academic year 2011/2012

16. Report on the operation of the Archive in year 2012 16 ;

17. Report on the operation of the Archive in year 2013

18. Report on the operation of the Archive in year $2014^{18}$.

6 The CSWU Archive, Plans and multi-annual reports of the CSWU Archive, current files with no archival signature. This report was created on the 25th of September 2007 as an appendix for the Resolution no. 1/2007 of the CSWU Archive Council adopted on 28th of September 2007.

7 The CSWU Archive, Plans and multi-annual reports of the CSWU Archive, current files with no archival signature. It is an appendix for the document no. AUKSW-033-1/08 dated on the 17th of April 2007. (requested by CSWU Rector's Office in order to prepare Rector 2007 annual report for Ministry of Science and Higher Education concerning the activities of the university).

8 Ibidem. It is an appendix for the document no. AUKSW-033-1/09 dated on the 15th of July 2009 addressed to the Rector of CSWU.

9 The CSWU Archive, CSWU Archive Council, current files with no archival signature. It is an appendix for the Resolution no. 3/2009 of the CSWU Archive Council adopted on the 15th of January 2009.

10 Ibidem. It is an appendix for the Resolution no. 1/2010 of the CSWU Archive Council adopted on the 14th of January 2010.

11 The CSWU Archive, Plans and multi-annual reports of the CSWU Archive, current files with no archival signature. It is an appendix for the Resolution no. 1/2011 of the CSWU Archive Council adopted on the 2nd of December 2011.

12 The CSWU Archive, CSWU Archive Council, current files with no archival signature. It is an appendix for the Resolution no. 4/2011 of the CSWU Archive Council adopted on the 16th of December 2011.

13 The CSWU Archive, CSWU Archive Council, current files with no archival signature (an appendix for the Resolution no. 1/2012 of the CSWU Archive Council adopted on the 11th of January 2012); AUKSW, Plans and annual reports on the activities of CSWU, current files with no archival signature (an appendix to the document no. AUKSW-033-1/12 dated on the 18th of January 2012 prepared for the director of State Archives of the Capital City of Warsaw).

14 The CSWU Archive, CSWU Archive Council, plans and annual reports, current files with no archival signature. It is an appendix to the document no. AUKSW-033-2/12 dated on the 23rd of August 2012 for Vice-Rector for Financial and Scientific Affairs concerning the annual report on the activities of CSWU Archive

15 Ibidem. It is an appendix for the document no. AUKSW-033-2/12 date on the 23rd of August 2012 for ViceRector for Financial and Scientific Affairs concerning the annual report on the activities of CSWU Archive.

16 The CSWU Archive, CSWU Archive Council, current files with no archival signature (appendix to CSWU Archive Council resolution no. 1/2013 dated on 22nd of February 2013); CSWU Archive, Plans and annual reports of CSWU Archive, current files with no archival signature (appendix to document no. AUKSW-033-1/13 dated on the 11th of March 2013).

17 The CSWU Archive, CSWU Archive Council, current files with no archival signature (appendix to CSWU Archive Council resolution no. 1/2014 dated on the 13th of January 2014); CSWU Archive, Plans and annual reports of CSWU Archive, current files with no archival signature (appendix to document no. AUKSW-033-1/14 dated on 13th of January 2014 for Vice-Rector for Financial Affairs and Infrastructure and the director of State Archive in Warsaw).

18 AUKSW, AUKSW Council, current files with no archival signature (an appendix for the CSWU Archive Council Resolution no. 1/2015 dated on the 8th of January 2015). 
All of the reports were drawn up following the same formula: they include organizational and administrative information, personnel data, information on management of capital assets of the university, substantive activities of the CSWU Archive and audits.

The organizational and administrative information in all reports consist of the circumstances and object of the CSWU Archive foundation, recently modified or altered regulations as well as office and archiving regulations on basis of which the Archive operates. Currently these are the following regulations and office and archiving standards agreed upon with the State Archive in Warsaw:

1. Cardinal Stefan Wyszyński University in Warsaw Archive Regulations introduced and implemented by the CSWU Rector directive no. 45/2007 on the creation of the regulations for Cardinal Stefan Wyszyński University Archive dated on the 29th of November 2007;

2. Cardinal Stefan Wyszyński University in Warsaw Archive Access Regulations introduced and implemented by the CSWU Rector decision no. 13/2002 on the Cardinal Stefan Wyszyński University in Warsaw Archive Access Regulations dated on the 19th of November 2002;

3. Administrative office instruction introduced and implemented by the CSWU Rector directive no. 5/06 dated on the 21st of February 2006 approved by the director of State Archive in Warsaw through document (signature: VI 401-17/06) issued on the 9th of February 2006.

4. Administrative office instruction introduced and implemented by the CSWU Rector directive no. 24/2009 dated on 29th of May 2009 approved by the director of State Archive in Warsaw through document (signature: VI 401-25/09) dated on the 14th of May 2009.

5. Uniform Material List of Files introduced and implemented by the CSWU Rector directive no. 11/2009 dated on the 3rd of April 2009 approved by the director of State Archive in Warsaw through document (signature: VI 401-25/09) issued on the 17th of March 2009.

Individual reports clearly represent the current state of the CSWU archive personnel: who is employed, on what position, what is his/her education, experience and seniority. The strategic issue of the archive space, especially storage room, is particularly interesting in the aspect of the university development and policy of its authorities. As the author learned during various archival conferences in country it is the primary and most basic issue in the majority of institutionalized archives, particularly university archives. The dynamic increase in the number of institutions of higher education in the years following political transformation and the related increase in the number of students resulted in the accrual of the end product of studies, i.e. students' files. And as it is known these files have to be kept and stored for a significant amount of time (students' files are BE50 category documents). It could be said that the number and size of the rooms assigned to the CSWU Archive dynamically evolved over 15 years of its existence and was the object of the particular attention and care of employees. Initially the CSWU Archive was confined to two rooms located in the Vicechancellor's office building located at Dewajtis 5 address in Warsaw: an office room with the surface area of $7.5 \mathrm{~m}^{2}$ and an archive storeroom with the surface area of $78 \mathrm{~m}^{2}$. In the academic year 2004/2005 the Archive was given two new storage rooms with the surface area of 6.5 and $10.9 \mathrm{~m}^{2}\left(17.4 \mathrm{~m}^{2}\right.$ in total) in the so called Connector. Towards the end of 2007 
the Archive was given a storeroom in the Building no. 18 located on the university campus under the Wóycickiego 1/3 address. In 2009 the CSWU Archive was given a reading room in the so called Old Building located at Dewajtis 5 address and two new storerooms in the Building no. 23 under the Wóycickiego 1/3 address. However, due to the organizational changes the CSWU Archive had to at the same time vacate the storeroom in the Building no. 18 at Wóycickiego 1/3 address. In 2010 one other archive room located in Building no. 23 at Wóycickiego 1/3 was re-assigned. Therefore, since the May of 2011 the archive has been occupying rooms located in three separate CSWU buildings located in Warsaw:

1. in the so called Old Building located at Dewajtis 5 - an office room, archive storeroom $\left(78 \mathrm{~m}^{2}\right)$ and a reading room (laboratory);

2. in the so called Connector located at Dewajtis 5 address - two storerooms $\left(6.5 \mathrm{~m}^{2}\right.$ and $\left.10.9 \mathrm{~m}^{2}\right)$

3. in building no. 23 at Wóycickiego $1 / 3$ address - a single storeroom no. , -13 ” $\left(18.75 \mathrm{~m}^{2}\right)$ (currently holding 80 metal shelves where non-archival documents with BC category of archives no higher than B10 are stored).

At that time the Archive possessed the total storage space of $114.15 \mathrm{~m}^{2}$.

The accommodation conditions of the CSWU archive changed significantly in the May of 2011. As the result of implementation of post-inspection recommendations of the State Archive in Warsaw on the 28th of July 2009 the archive was given a new building located on the prof. dr. hab. Ryszard Rumianek, CSWU Rector, Campus under the Wóycickiego 1/3, Warsaw, address (building no.3). To meet the archive's requirements the new building was adapted from a spacious lecture hall and complies with the requirements of PN-ISO 11799:2006 standards. It has usable surface area of $218.52 \mathrm{~m}^{2}$, cubic area of $1000 \mathrm{~m}^{3}$, dimensions in projection $24,6 \times 10,7 \mathrm{~m}$ and useable height of $3.0 \mathrm{~m}$ on average. The building discussed herein-above includes:

1. files storeroom - usable surface area of $139.80 \mathrm{~m}^{2}$ (up until 2015 equipped with sliding and stationary metal racks, 855 shelves in total);

2. audio-visual materials storeroom - usable surface area of $4.03 \mathrm{~m}^{2}$ (equipped with stationary metal racks, 15 shelves in total);

3. reading room - equipped with one seat for clients $-4.03 \mathrm{~m}^{2}$;

4. administrative office with social facilities $-27.82 \mathrm{~m}^{2}$;

5. technical rooms, including ventilation room $-21.09 \mathrm{~m}^{2}$ in total.

Due to the use of state-of-the-art air conditioning and ventilation system the archive storerooms in the new building constantly maintain constant temperature and air humidity. Additionally Building no.3 is secured and protected against fire, break-in and forced entry. Unfortunately when given the use of the new Building no. 3 at Wóycickiego 1/3 address the Archive lost three old storerooms located on Dewajtis street campus (approx. 600 shelves in total) which were reassigned to other CSWU units. As a result the new storage facility was filled with already existing documentation handed over to the CSWU Archive. Influx of new documents filled storerooms in Building no. 3 entirely by the end of $2014^{19}$.To recapitulate, the last report states that there are $162.58 \mathrm{~m}^{2}$ of the available usable surface $\operatorname{area}^{20}$.

\footnotetext{
19 See:Report on the activities of CSWU Archive in 2014 in: CSWU Archive, Plans and annual reports of CSWU Archive, current files with no archival signature.

20 Ibidem.
} 
Starting with the 2008 report on CSWU Archive activities all future reports include information concerning cooperation of the Archive with the general directorate of State Archives in the field of establishing nationwide internet archives: SEZAM (System Ewidencji Zasobu Archiwalnego) [tn - Archive Materials Registry System] and IZA (Inwentarze Zespołów Archiwalnych) [tn - Archival Fonds Inventory].Furthermore, the CSWU Archive cooperates and consults various current issues with other universities and public institutions.

The final result of 15 years of operation of the CSWU Archive is an impressive collection of archival resources which by the end of 2014 consisted of:

1. Cardinal Stefan Wyszyński University in Warsaw complex open fond named „Uniwersytet Kardynała Stefana Wyszyńskiego w Warszawie” [tn - Cardinal Stefan Wyszyński University in Warsaw] consisting of archive materials and files concerning ACT and CSWU operation and activities in the $1954-2014$ period ( $901.16 \mathrm{mb}$ in total, $111.79 \mathrm{mb}$ of A category materials and $789.37 \mathrm{mb}$ of B category materials);

2. CSWU Archive photographic collection containing photographic materials from 1975-2011 period (16240 archive units, hereinafter a.u.);

3. CSWU Archive audio recordings collection containing records from the 1969-1992 period (260 a.u.);

4. CSWU collection of video recordings containing records from 2001-present period (10 a.u.).

Beginning with the CSWU Annual Report 2010 general information concerning development of this particular resource became available. This is best represented by the following tabular listing.

Table no.1. Development of the CSWU Archive resources in 2010-2014 period

\begin{tabular}{|c|c|c|c|c|c|c|c|c|}
\hline $\begin{array}{l}\text { CSWU } \\
\text { Arcive } \\
\text { report }\end{array}$ & $\begin{array}{l}\text { CSWU } \\
\text { Archive } \\
\text { Fond } \\
\text { influx }\end{array}$ & $\begin{array}{c}\text { Photography } \\
\text { Collection } \\
\text { influx }\end{array}$ & $\begin{array}{c}\text { General } \\
\text { increase in } \\
\text { the amount of } \\
\text { documentation } \\
\text { (in a.u.) }\end{array}$ & $\begin{array}{c}\text { General } \\
\text { increase in } \\
\text { the amount of } \\
\text { documentation } \\
\text { in mb) }\end{array}$ & $\begin{array}{c}\text { Total } \\
\text { amount of } \\
\text { documentation } \\
\left(\text { in } \mathrm{mb}^{\mathrm{A}}\right)\end{array}$ & $\begin{array}{l}\text { Cat. A. files } \\
\text { (as of the } \\
\text { end of Acc. } \\
\text { Year) (in } \\
\mathrm{mb}^{\mathrm{A}} \text { ) }\end{array}$ & $\begin{array}{c}\text { Cat. A. } \\
\text { audiovisual } \\
\text { documentation } \\
\text { (as of the end of } \\
\text { Acc. Year) (in } \\
\mathrm{mb}^{\mathrm{A}} \text { ) }\end{array}$ & $\begin{array}{l}\text { Cat. B. } \\
\text { documentation (as } \\
\text { of the end of Acc. } \\
\text { Year) (in } \mathrm{mb}^{\mathrm{A}} \text { ) }\end{array}$ \\
\hline 2010 & 4 & - & 672 & 7,6 & 506,33 & - & - & - \\
\hline 2011 & 21 & 1 & 10153 & 94,86 & 601,19 & 72,55 & 7,66 & 520,98 \\
\hline 2012 & 49 & - & 10307 & 125,30 & 739,18 & 92,72 & 7,66 & 638,80 \\
\hline 2013 & 42 & - & 6036 & 83,17 & 829,23 & 100,19 & 7,66 & 720,71 \\
\hline 2014 & 41 & - & 5480 & 74,71 & 901,16 & 103,43 & 7,66 & 789,37 \\
\hline
\end{tabular}

${ }^{\text {A }}$ state at the end of accounting year, source: own compiled data 
Substantive activity of the CSWU Archive is best represented by the following table:

Table no. 2. Substantive activity of the CSWU Archive according to 2003-2015 reports

\begin{tabular}{|c|c|c|c|c|c|c|c|c|}
\hline $\begin{array}{c}\text { CSWU } \\
\text { Arcive } \\
\text { report }\end{array}$ & $\begin{array}{c}\text { No. of units } \\
\text { handing } \\
\text { over files }\end{array}$ & $\begin{array}{c}\text { Size of } \\
\text { influx }\end{array}$ & $\begin{array}{c}\text { No. of } \\
\text { received } \\
\text { archival } \\
\text { units }\end{array}$ & $\begin{array}{c}\text { Size of the } \\
\text { received } \\
\text { documentation } \\
\text { (in mb) }\end{array}$ & $\begin{array}{c}\text { Destruction } \\
\text { of obsolete } \\
\text { documentation } \\
\text { (in mb) }\end{array}$ & $\begin{array}{c}\text { Scientific } \\
\text { queries } \\
\text { (Archival } \\
\text { Fond Users) }\end{array}$ & $\begin{array}{c}\text { Queries } \\
\text { conducted for } \\
\text { other CSWU } \\
\text { organizational } \\
\text { units }\end{array}$ & $\begin{array}{c}\text { Social } \\
\text { queries }\end{array}$ \\
\hline $2002 / 2003^{\wedge}$ & 6 & no data & 1149 & 20,90 & - & 1 & 552 & no data \\
\hline $2003 / 2004^{A}$ & 8 & no data & 4804 & 64,20 & - & 12 & 374 & no data \\
\hline $2004 / 2005^{\text {A }}$ & 10 & no data & 4384 & 36,62 & - & 13 & 289 & no data \\
\hline $2005 / 2006^{\text {A }}$ & 5 & no data & 2276 & 29,72 & 15,70 & 7 & 409 & no data \\
\hline 2006 & 4 & no data & 1511 & 26,55 & $15,70^{\text {B }}$ & 8 & 370 & no data \\
\hline 2007 & 13 & no data & 4876 & 67,32 & - & 5 & 629 & no data \\
\hline 2008 & 4 & no data & 1510 & 11,50 & - & 3 & 296 & no data \\
\hline 2009 & 2 & no data & 701 & 3,15 & 12,07 & 22 & 278 & no data \\
\hline 2010 & 2 & 4 & 672 & 7,60 & - & 4 & 208 & no data \\
\hline 2011 & 7 & 22 & 10153 & 94,86 & - & 10 & 230 & no data \\
\hline 2012 & 20 & 49 & 10307 & 125,30 & - & 6 & 260 & 9 \\
\hline 2013 & 13 & 42 & 6036 & 83,17 & - & 11 & 186 & 3 \\
\hline 2014 & 15 & 41 & 5480 & 74,71 & - & 36 & 160 & 3 \\
\hline
\end{tabular}

A Academic year

B Repetition of the 2005/2006 academic year CSWU report data, source: own compiled data

The CSWU Archive reports also cover the scientific work of its employees, their active and passive participation in numerous national archival conferences, symposia and scientific seminars (Warsaw, Poznań, Kule, Koszalin, Legnica, Katowice, Święty Krzyż, Toruń, Kraków). The results of participation in these and other events consist of scientific publications of the researchers and scientists employed in the CSWU Archive published in various periodicals (“Rocznik Mazowiecki”, „Dzieje dawne i nowe”, „Saeculm Christianum”). The reports are also evidence of the educational and didactic work of the Archive employees: archiving techniques training for first year students of history at the CSWU, internships for students of the archival specialization at the CSWU History and Social Sciences degree course as well as archive and office training for the CSWU employees who are not academic teachers. It is also worth to note and emphasize participation of the CSWU Archive employees in works on formulating and establishing collegiate regulations for office and archive work (such as administrative office instruction, uniform material files list, archive instruction, archive regulations and archive access regulations) as well as the audit work and substantive support provided to other units.

Reports on CSWU Archive operation also document the external audits conducted therein in years 2002, 2005, 2009 and 2013 as well as an internal audit - in 2013. 
Starting with the 2009 report on the operation of CSWU Archive the subsequent reports also record the meetings which CSWU Archive Council participated in during the accounting year and resolutions passed during the meetings.

Furthermore, the reports are also the evidence of the titanic work and effort archive employees exerted during compiling and processing of the files inherited from Academy of Catholic Theology in Warsaw. Great efforts were made to convert audio materials concerning ACT from analog to digital media, scan photographs and visual resources handed over to the CSWU Archive by ACT/CSWU and to prepare record keeping aides.

Archive registry and inventory aides created and compiled by the employees of the Archive also make working with the fond convenient and efficient. These aides include: deliveryreceiver lists, register of delivery-receiver lists, inventory of the CSWU Archive collection of audio records, chronological-subject catalogue of the CSWU Archive Photography collection, catalogue of negative and positive assets of the CSWU Archive Photography collection, inventory of film resources of the CSWU archive, CSWU Archive film collection index.

The annual and multi-annual reports on the operation and activity of the CSWU Archive, lodged by employees with either the State Archive in Warsaw or with the university authorities, provide an excellent insight into operation of the Archive. The reports include a section devoted to statistics concerning the amount and condition of stored archival units divided into archival resources and non-archival documents, a section listing information pertaining to the amount of archival units divided into organizational cells taken over, section about the deficient non-archival documents and, finally, about the files shared, lent and made available. The descriptive part of these reports consists mainly of signaling the CSWU Archive accommodation and storeroom difficulties, performed audits and related recommendations and realization of said recommendations. It must be stressed that the dynamics of the Archive operation are the result of the support provided by the efforts of the Archive Council, its directives and resolutions as well as the cooperation with other facilities and units of this kind in Poland. For instance through participation in scientific conferences and maintaining contact with the community of Polish archivists.

In summary, the CSWU archive during its period of activity pointedly consolidated its position at the university by realizing its primary objective: collecting and storing files after the period of their storage in other organizational units, as determined by the administrative office instruction, elapsed. The Archive is to meet two basic requirements and fulfill two basic tasks: relieve other administrative units of the university from the documentation unnecessary for current operation but which is still to be kept according to obligatory storage period as well as secure and store valuable archival materials. The awareness of the possession of such valuable collection of documentation, from the historical point of view for instance, should be constantly prevalent and considered in making decisions concerning this esteemed institution of the university. 


\section{The operation of the Cardinal Stefan Wyszyński University (Warsaw) archive based on its reports from 2003 to 2015 Summary}

The 15th anniversary of the establishment of the Cardinal Stefan Wyszyński University (UKSW) archive is a good moment to reflect on its operation. Its annual reports enable us to recognize the scale and quality of the archive's operation. Reports prepared between 2003 and 2015 for various purposes and authorities show how the archive has fulfilled its basic duties.

The quality of UKSW's archive is monitored by the State Archive in Warsaw.As ainterfaculty unit of UKSW, the archive also comes under the authority of one of the University's deputy vice-chancellors.The archive mainly reports to these principal bodies on an annual basis.The archive holds the records of the Warsaw Theological Academy which was later transformed into UKSW.

Keywords: Archive, reporting, reports, documentation, records, archival material, ar-chive record
About the author: Roman Poletyło: graduate of the Church Historical and Social Sciences Department of the Christian Theology Academy in Warsaw, currently employed in Cardinal Stefan Wyszyński University in Warsaw. 